\title{
Pelatihan Regulasi Emosi untuk Meningkatkan Kesejahteraan Subjektif Orang dengan Hipertensi Esensial
}

\author{
Dwi Widarna Lita Putri', Qurotul Uyun', Indahria Sulistyarini ${ }^{2}$ \\ ${ }^{1}$ Prodi Bimbingan dan Konseling Islam Fakultas Dakwah dan Ilmu Komunikasi Universitas \\ Islam Negeri Mataram \\ 2Prodi Psikologi Fakultas Psikologi dan Ilmu Sosial Budaya Universitas Islam Indonesia \\ e-mail: litawaspadali26@gmail.com
}

\begin{abstract}
This research aims at identifying the effect of emotion regulation training to increase subjective well being of people with essential hypertension. The subject of the research was the twenty six people with essential hypertension. Hypertension will improve emotion regulation after getting training to people with essential hypertension who do not follow the training of emotion regulation. The research design used was control group design. The quantitatif analysis using independent sample t-tes at identifying the effect of emotion regulation training to increase subjective well being of people with essential hypertension were given training in emotion regulation training with a control group that was not given training in emotion regulation. Result of research that is all aspect of subjective well being show existence of difference which signifikan people with essential hypertension in the control group with the experimental group were given treatment at the end of the test scores of subjective well-being in the form of life satisfaction with $p=0.002$ $(p<0.01)$, positively affect the value of $p=0.03(p<0,01)$ and negatively affect the value of $\mathrm{p}=0.005(\mathrm{p}<0.01)$.
\end{abstract}

Key Words : Subjective well being, Emotion regulation, People with essential hypertension

\begin{abstract}
Abstrak. Penelitian ini bertujuan untuk mengetahui pengaruh pelatihan regulasi emosi terhadap peningkatan kesejahteraan subjektif orang dengan hipertensi. Subjek dalam penelitian ini adalah 26 subjek yang mengalami hipertensi esensial. Hipotesis yang diajukan dalam penelitian ini adalah ada perbedaan kesejahteraan subjektif orang dengan hipertensi esensial yang mengikuti pelatihan regulasi emosi dengan orang dengan hipertensi esensial yang tidak mengikuti pelatihan regulasi emosi. Desain penelitian yang digunakan adalah control group design. Analisis kuantitatif menggunakan uji independen sample t-tes untuk mengetahui ada atau tidaknya pengaruh pelatihan regulasi emosi terhadap peningkatan kesejahteraan subjektif pada kelompok eksperimen yang diberikan pelatihan-pelatihan regulasi emosi dengan kelompok kontrol yang tidak diberikan pelatihan regulasi emosi. Hasil penelitian, berupa semua aspek kesejahteraan subjektif menunjukkan adanya perbedaan yang sangat signifikan, orang dengan hipertensi esensial pada kelompok kontrol dengan kelompok eksperimen yang diberikan perlakuan dengan nilai tes akhir kesejahteraan subjektif yang berupa kepuasan hidup dengan nilai $\mathrm{p}=0,002(\mathrm{P}<0,01)$, afek positif dengan nilai $\mathrm{p}=0,03(\mathrm{P}<0,01)$ dan afek negatif dengan nilai $\mathrm{P}=0,005(\mathrm{P}<0,01)$.
\end{abstract}

Kata kunci : kesejahteraan subjektif, regulasi emosi, orang dengan hipertensi esensial

\section{Pendahuluan}

Presentase penderita hipertensi secara umum saat ini paling banyak ditemukan di negara berkembang seperti Indonesia. Berdasarkan beberapa sumber data yang didapatkan penyakit tekanan darah tinggi atau dikenal dengan istilah hipertensi merupakan penyebab kematian nomor 3 setelah stroke dan tuberkulosis, yakni mencapai 6,7\% dari populasi 
kematian pada semua umur di Indonesia (Depkes RI 2014). Hipertensi adalah gangguan sistem peredaran darah yang menyebabkan suatu keadaan di mana tekanan darah seseorang $\geq 140 \mathrm{mmHg}$ (tekanan sistolik) dan atau $\geq 90 \mathrm{mmHg}$ (tekanan diastolik) Uoin National Committee On PreventionDetection, Evaluation, and Treatment of High Pressure VII, 2003).

Berdasarkan hasil Riset Kesehatan Dasar (Riskesdas) Balitbangkes tahun 2012 menunjukkan prevalensi secara nasional mencapai 31,7\% (Depkes RI, 2014). Selanjutnya berdasarkan Riskesdas tahun 2012 pula menunjukkan bahwa hipertensi umumnya muncul pada orang dengan lanjut usia tetapi sekarang terjadi pada usia 20 sampai 55 tahun sebanyak 30\%. Perubahan gaya hidup modern serba otomatis dan kurang efektif membawa konsekuensi penyakit degeneratif salah satunya hipertensi.

Hipertensi di Indonesia khususnya di Daerah Istimewa Yogyakarta (DIY) pada Kabupaten Sleman, ancaman penyakit tidak menular seperti hipertensi menjadi masalah kesehatan masyarakat (Dinkes Sleman, 2014). Didukung dengan adanya data penyakit tidak menular. Pada tahun 2013 di puskesmas Kabupaten Sleman, hipertensi ringan menduduki peringkat pertama penyakit tidak menular dengan presentase sebesar $71 \%$ atau 6.532 dan pada umumnya merupakan hipertensi primer atau esensial. Hampir 90\% orang dengan hipertensi mengalami hipertensi primer atau esensial dikarenakan penyebabnya adalah multifaktor, baik dari faktor genetik maupun lingkungan. Dikategorikan hipertensi esensial jika tekanan darah lebih tinggi dari 140/90 mmhg.

Hipertensi esensial menimbulkan reaksi psikologis bagi penderitanya seperti kebingungan, kecemasan, putus asa, dan kesedihan yang mendalam menyangkut keadaan dirinya. Gambaran hipertensi di lapangan berdasarkan wawancara tidak terstruktur pada 5 orang dengan hipertensi esensial yang bertempat tinggal di wilayah dusun binaan Puskesmas Ngemplak 1 Bimomartani Sleman Yogyakarta, diperoleh data bahwa sebagian besar orang menyatakan merasa takut setelah mengetahui bahwa tekanan darahnya naik, merasa gelisah sehingga tidak dapat tidur cepat dan nyenyak karena merasa dengan penyakitnya tersebut akan mengantarkannya kepada kematian. Selain itu orang dengan hipertensi merasa bingung karena telah berobat cukup lama tetapi tidak kunjung sembuh.

Sujana (2012) menyatakan ada sejumkah gejala yang dapat dialami oleh penderita hipertensi seperti sakit kepala, rasa pegal, dan tidak nyaman pada tengkuk, perasaan berputar serasa ingin jatuh berdebar atau detak jantung terasa lebih cepat, telinga berdenging, penglihatan kabur, mimisan, dan cepat lelah. Gejala-gejala tersebut dapat mengganggu kenyaman, kesejahteraan, dan aktivitas sehari-hari.

Menurut DeRidder, Geenan, Kuijer, \& Van Middendorp (2008), setelah didiagnosa penyakit kronis, pasien dihadapkan pada situasi baru, sehingga harus menyesuaikan diri. Sebagian dari pasien dapat menyesuaikan diri dengan baik, tetapi sebagian membutuhkan 
waktu yang lebih lama, bahkan ada yang tidak berhasil menyesuaikan diri. Berbagai masalah psikologis yang dihadapi penderita akan menimbulkan stres bagi penderitanya berupa rasa sedih dan kehilangan harapan. Penelitian yang pernah dilakukan Prasetyoarini dan Prawesti (2012), salah satu penyebab meningkatnya darah pada penderita hipertensi adalah stres emosional.

Menurut James A McCubbin, seorang Professor Psikologi dan rekannya dari Clemson University Amerika Serikat telah membuktikan bahwa penderita hipertensi cenderung mengalami penurunan kemampuan dalam mengenali emosi negatif seperti rasa marah, takut dan sedih. Untuk itu perlu usaha untuk menetralisir emosi negatif tersebut dan meningkatkan emosi positif dalam diri penderita sehingga mampu memberikan kebahagiaan dan kepuasan dalam hidup pada penderita hipertensi dan hal ini dapat membantu upaya manajemen hipertensi.

Orang dengan hipertensi terkadang kurang mampu mengontrol emosi yang bersifat negatif. Emosi negatif yang dirasakan biasanya diungkapkan dengan cara yang tidak tepat. Regulasi emosi adalah salah satu cara yang dapat dilakukan untuk membantu orang dengan hipertensi memfasilitasi kebutuhan emosionalnya. Regulasi emosi adalah kemampuan yang dimiliki seseorang untuk menilai, mengatasi, mengelola, dan mengungkapkan emosi dengan tepat dalam rangka mencapai keseimbangan emosional (Greenberg, 2002). Orang dengan hipertensi perlu dilatih dan diberikan bekal keterampilan dalam hal meregulasi emosinya, sehingga akan mampu menilai emosi yang dirasakan, mengatur emosi serta mengungkapkan emosi positif dan negatif secara tepat. Orang dengan hipertensi yang mampu melakukan regulasi emosi akan mampu mengurangi munculnya stres dan tekanan darah tinggi.

Pada penelitian ini upaya pengenalan regulasi emosi pada orang dengan penderita hipertensi dilakukan dengan menggunakan pendekatan pelatihan. Pendekatan pelatihan dilakukan karena pelatihan merupakan suatu metode pembelajaran yang bertujuan untuk mengubah aspek kognitif, afektif, serta hasil keterampilan atau keahlian (Kikpatrick dalam Salas dkk, 2001).

Penelitian ini dimaksud agar orang dengan hipertensi dapat mempelajari regulasi emosi sehingga dapat menerapkannya dalam kehidupan sehari-hari. Orang dengan hipertensi mampu mengenali emosi dan memodifikasi emosi yang timbul dalam perjalanan penyakitnya seperti sedih, cemas, takut, dan stres menjadi lebih adaptif. Kemampuan memodifikasi emosi yang negatif menjadi emosi yang lebih adaptif akan meningkatkan kesejahteraan subjektif. Menurut Diener, dkk (2003) kebahagiaan diartikan sebagai penilaian individu terhadap kehidupannya. Selain itu kebahagiaan juga melibatkan kepuasan (kepuasan secara umum dan spesifik pada ranah kehidupan tertentu), afek positif dan afek negatif. Lebih lanjut adanya perasaan bahagia, rasa puas, sejahtera, dan positif terhadap 
kehidupannya serta mampu mencapai tujuan hidup dan cita-citanya. Dalam situasi dan kondisi yang berbeda-beda, setiap inidvidu dapat memaknai perasaan pada dirinya menurut pandangan subjektifnya. Kebahagiaan, kesejahteraan, dan rasa puas terhadap hidupnya yang bersifat subjektif itu kemudian dikenal dengan istilah kesejahteraan subjektif.

Kesejahteraan subjektif inilah dapat membantu orang dengan hipertensi dalam menjalani manajemen hipertensi dalam upaya mengendalikan tekanan darah. Dengan pemaparan tersebut peneliti merasa tertarik melakukan penelitian ini, yaitu membantu pengelolaan hipertensi dari sisi psikologis. Penanganan psikologis ini akan dilakukan dengan memberikan pelatihan regulasi emosi dalam upaya peningkatan kesejahteraan subjektif pada orang dengan hipertensi.

Penelitian ini bertujuan untuk mengetahui pengaruh pelatihan regulasi emosi terhadap peningkatan kesejahteraan subjektif pada orang dengan hipertensi. Manfaat teoretis yaitu memperluas dan memperdalam kajian teori di bidang klinis dan kesehatan. Manfaat praktis berupa implikasi hasil penelitian dapat digunakan dalam menangani pasien dengan hipertensi. Hipotesis yang diajukan dalam penelitian ini adalah ada perbedaan kesejahteraan subjektif orang dengan hipertensi yang mengikuti pelatihan regulasi emosi dengan orang dengan hipertensi yang tidak mengikuti pelatihan regulasi emosi. Orang dengan hipertensi memiliki kesejahteraan subjektif berupa kepuasan dan afektif yang tinggi setelah mendapatkan pelatihan regulasi emosi dibandingkan dengan orang dengan hipertensi yang tidak mendapatkan pelatihan regulasi.

\section{Metode}

Penelitian ini menggunakan desain kuasi-eksprimental. Rancangan eksperimen yang digunakan dalam penelitian ini adalah tes awal tes akhir control group design, yaitu metode eksperimen yang berusaha untuk membandingkan efek suatu perlakuan terhadap variabel tergantung yang diuji dengan membandingkan variabel tergantung pada kelompok eksperimen setelah dikenai perlakuan dengan kelompok kontrol yang tidak dikenai perlakuan. Pemilihan subjek ditetapkan dengan cara maching dengan kriteria usia, tekanan darah, jenis hipertensi, intensitas, dan skor kesejahteraan subjektif yang telah ditentukan (purposive sampling).

Kriteria subjek dalam penelitian ini adalah berjenis kelamin laki-laki dan perempuan, berusia antara 35 sampai 55 tahun, bersedia mengikuti pelatihan sampai selesai, menderita hipertensi maksimal 1 bulan dan menderita hipertensi esensial serta memiliki kesejahteraan subektif dengan kategori kepuasan hidup dangat tidak puas sampai tidak puas serta menunjukkan jumlah skor afek negatif yang lebih tinggi dari pada jumlah afek positif. Berdasarkan kriteria tersebut peneliti mendapatkan 26 subjek. Dari 26 subjek maka dibagi 
menjadi 2 kelompok yaitu 13 subjek menjadi kelompok eksperimen dan 13 subjek lainnya menjadi kelompok kontrol. Pemilihan kelompok eksperimen berdasarkan letak geografis di mana rumah subjek satu dengan yang lainnya berdekatan dengan lokasi pelaksanaan pelatihan.

\section{Hasil}

Berdasarkan uji asumsi yang telah dilakukan, yaitu uji normalitas yang datanya berdistribusi normal, maka hal ini memenuhi syarat untuk melakukan uji hipotesis dengan menggunakan uji independen sample t-tes. Uji independen sample t-tes merupakan bagian dari statistik inferensial parametrik (uji beda). Dasar pengambilan keputusan pada uji independen t-tes adalah jika nilai signifikansi atau sig.(2-tailed) $<0,05$, maka diperoleh data terdapat pengaruh signifikan yang dihasilkan dari intervensi yang dilakukan. Selanjutnya jika nilai signifikansi atau sig.(2-tailed) <0,01, maka diperoleh data terdapat pengaruh sangat signifikan yang dihasilkan dari intervensi yang dilakukan. Syarat untuk menggunakan uji independen sample t-tes pada uji hipotesis adalah hasil uji normalitas yang berdistribusi normal, data harus homogen dan jumlah data kurang dari 30 aitem. Berdasarkan alasan tersebut maka dilakukanlah uji hipotesis dengan menggunakan uji independen sample t-tes. Hasil analisis data kesejahteraan subjektif yang terdiri dari SWLS (Satisfactions with Life Scale), afek positif, dan afek negatif dapat dilihat pada tabel berikut ini:

\section{Uji Beda dengan Menggunakan Skor Skala SWLS (Satisfactions with Life Scale)}

Tabel 1.

Hasil Uji Hipotesis SWLS (Satisfactions with Life Scale)

\begin{tabular}{|l|l|l|}
\hline & Sig.(2-failed) / P & Keterangan \\
\hline Tes Awal & 0,808 & Tidak Signifikan \\
\hline Tes Akhir & 0,002 & Sangat Signifikan \\
\hline Tindak Lanjut & 0,000 & Sangat signifikan \\
\hline
\end{tabular}

Skor tes awal menunjukkan tidak ada perbedaan SWLS (Satisfaction with Life Scale) antara kelompok eksperimen dan kelompok kontrol dengan Sig.(2-failed) p = 0,808 ( $p>0,01)$. Hal tersebut sesuai dengan asumsi bahwa sebelum mendapatkan intervensi seluruh subjek masih pada kategori yang sama. Hal yang berbeda ditunjukkan pada tabel tersebut pada tes akhir, bahwa ada perbedaan SWLS (Satisfaction with Life Scale) antara kelompok eksperimen dan kelompok kontrol pada saat tes akhir dengan nilai Sig.(2-failed) $p=0,002(p<0,01)$. Hal ini menunjukkan menunjukkan ada kesesuaian dengan asumsi sebelumnya bahwa setelah mendapatkan intervensi, kelompok eksperimen mengalami perubahan pada skor SWLS 
(Satisfaction with Life Scale). Selanjutnya pada tabel saat tindak lanjut menunjukkan ada perbedaan SWLS (Satisfaction with Life Scale) antara kelompok eksperimen dengan kelompok kontrol dengan nilai sig. (2-failed) $p=0,000(p<0.01)$. Hal ini sesuai dengan asumsi sebelumnya bahwa setelah mendapatkan intervensi, akan mengalami perubahan pada skor SWLS (Satisfaction with Life Scale).

\section{Uji Beda dengan Menggunakan Skor Skala Afek Positif}

Tabel 2

\section{Hasil Uji Hipotesis Afek Positif}

\begin{tabular}{|l|l|l|}
\hline & Sig. (2-failed) / P & Keterangan \\
\hline Tes Awal & 0,070 & Tidak Signifikan \\
\hline Tes Akhir & 0,003 & Sangat Signifikan \\
\hline Tindak Lanjut & 0,000 & Sangat Signifikan \\
\hline
\end{tabular}

Skor tes awal menunjukkan tidak ada perbedaan afek positif antara kelompok eksperimen dan kelompok kontrol dengan Sig.(2-failed) $p=0,070(p>0,01)$. Hal tersebut sesuai dengan asumsi bahwa sebelum mendapatkan intervensi seluruh subjek masih pada kategori yang sama. Hal yang berbeda ditunjukkan pada tabel tersebut pada tes akhir, bahwa ada perbedaan afek positif antara kelompok eksperimen dan kelompok kontrol pada saat tes akhir dengan nilai Sig. (2-failed) p = 0,003 ( $<<0,01)$. Hal ini menunjukkan menunjukkan ada kesesuaian dengan asumsi sebelumnya bahwa setelah mendapatkan intervensi, kelompok eksperimen mengalami perubahan pada skor afek positif. Selanjutnya pada tabel saat tindak lanjut menunjukkan ada perbedaan afek positif antara kelompok eksperimen dengan kelompok kontrol dengan nilai sig. (2-failed) $p=0,000(p<0.01)$. Hal ini sesuai dengan asumsi sebelumnya bahwa setelah mendapatkan intervensi, akan mengalami perubahan pada skor afek positif.

Uji Beda dengan Menggunakan Skor Skala Afek Positif

Tabel 3

Hasil Uji Hipotesis Afek Negatif

\begin{tabular}{|l|l|l|}
\hline & Sig.(2-failed) / P & Keterangan \\
\hline Tes Awal & 0,132 & Tidak Signifikan \\
\hline Tes Akhir & 0,005 & Sangat Signifikan \\
\hline Tindak Lanjut & 0,000 & Sangat Signifikan \\
\hline
\end{tabular}


Skor tes awal menunjukkan tidak ada perbedaan afek negatif antara kelompok eksperimen dan kelompok kontrol dengan Sig.(2-failed) $p=0,132(p>0,05)$. Hal tersebut sesuai dengan asumsi bahwa sebelum mendapatkan intervensi seluruh subjek masih pada kategori yang sama. Hal yang berbeda ditunjukkan pada tes akhir, bahwa ada perbedaan signifikan afek negatif antara kelompok eksperimen dan kelompok kontrol pada saat tes akhir dengan nilai Sig.(2-failed) $p=0,005(p<0,01)$. Hal ini menunjukkan adanya kesesuaian dengan asumsi sebelumnya bahwa setelah mendapatkan intervensi, kelompok eksperimen mengalami perubahan pada skor afek negatif. Selanjutnya pada tindak lanjut menunjukkan ada perbedaan afek negatif antara kelompok eksperimen dan kelompok kontrol dengan nilai Sig.(2-failed) $p=0,000(p<0,01)$. Hal ini menunjukkan menunjukkan ada kesesuaian dengan asumsi sebelumnya bahwa setelah mendapatkan intervensi, kelompok eksperimen mengalami perubahan pada skor afek negatif.

\section{Hasil Analisis Masing-masing Kelompok}

Perbandingan skor tes awal dan tes akhir pada masing-masing kelompok dapat dilihat pada grafik berikut ini:

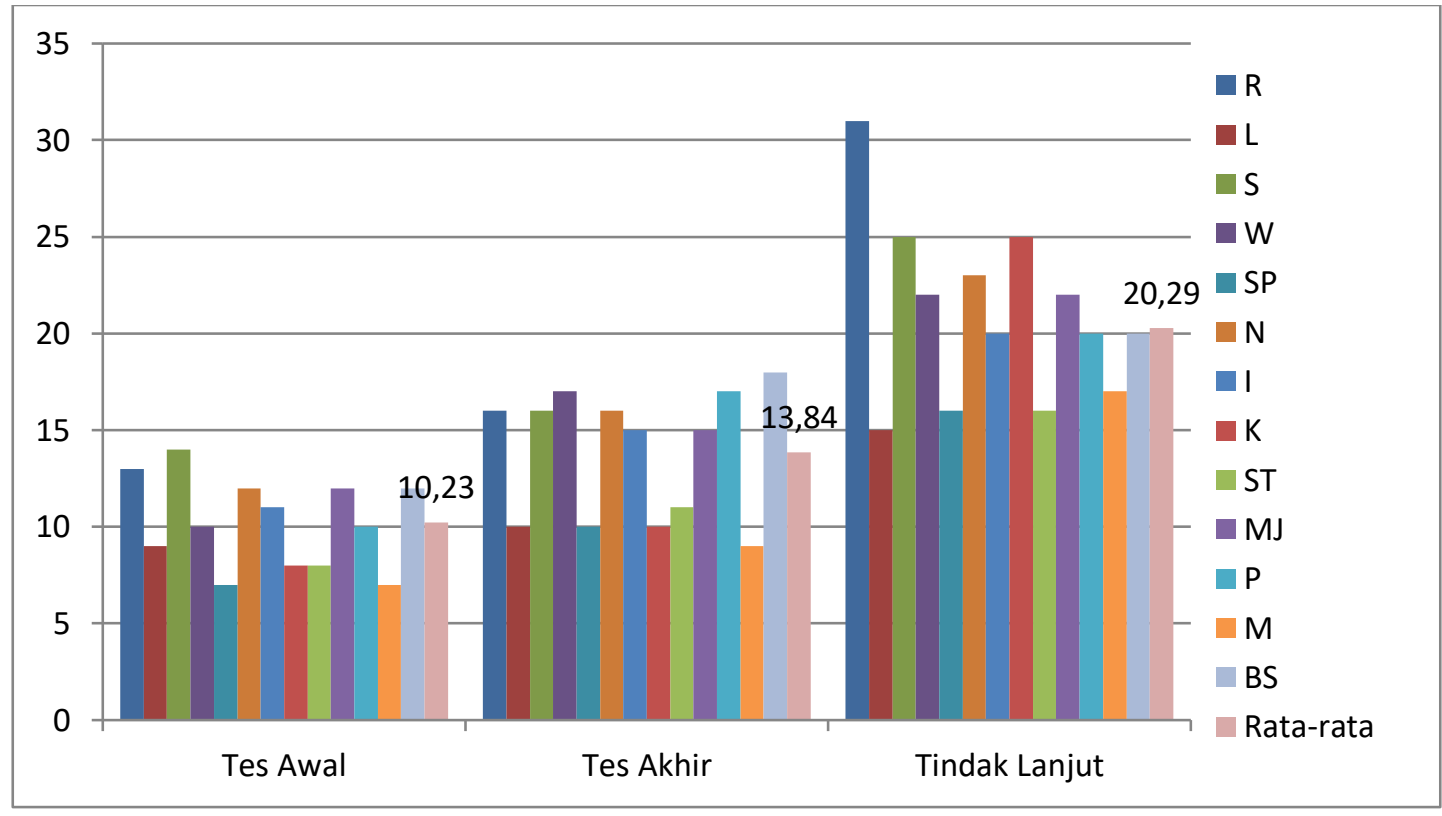

Gambar 1. Grafik Perubahan Skor SWLS (Satisfaction with Life Scale) pada Tes Awal, Tes Akhir dan Tindak Lanjut Kelompok Eksperimen

Pada kelompok eksperimen terjadi perubahan rerata skor SWLS (Satisfaction with Life Scale), yaitu dari 10,23 pada tes awal menjadi 13,84 pada tes akhir. Kedua angka tersebut terjadi peningkatan walau masih dalam kategori yang sama (kategori tidak puas) dan pada saat tindak lanjut menjadi 20,29. Angka tersebut mengalami peningkatan dan begitu juga dengan kategorinya dari kategori tidak puas menjadi kategori puas. 


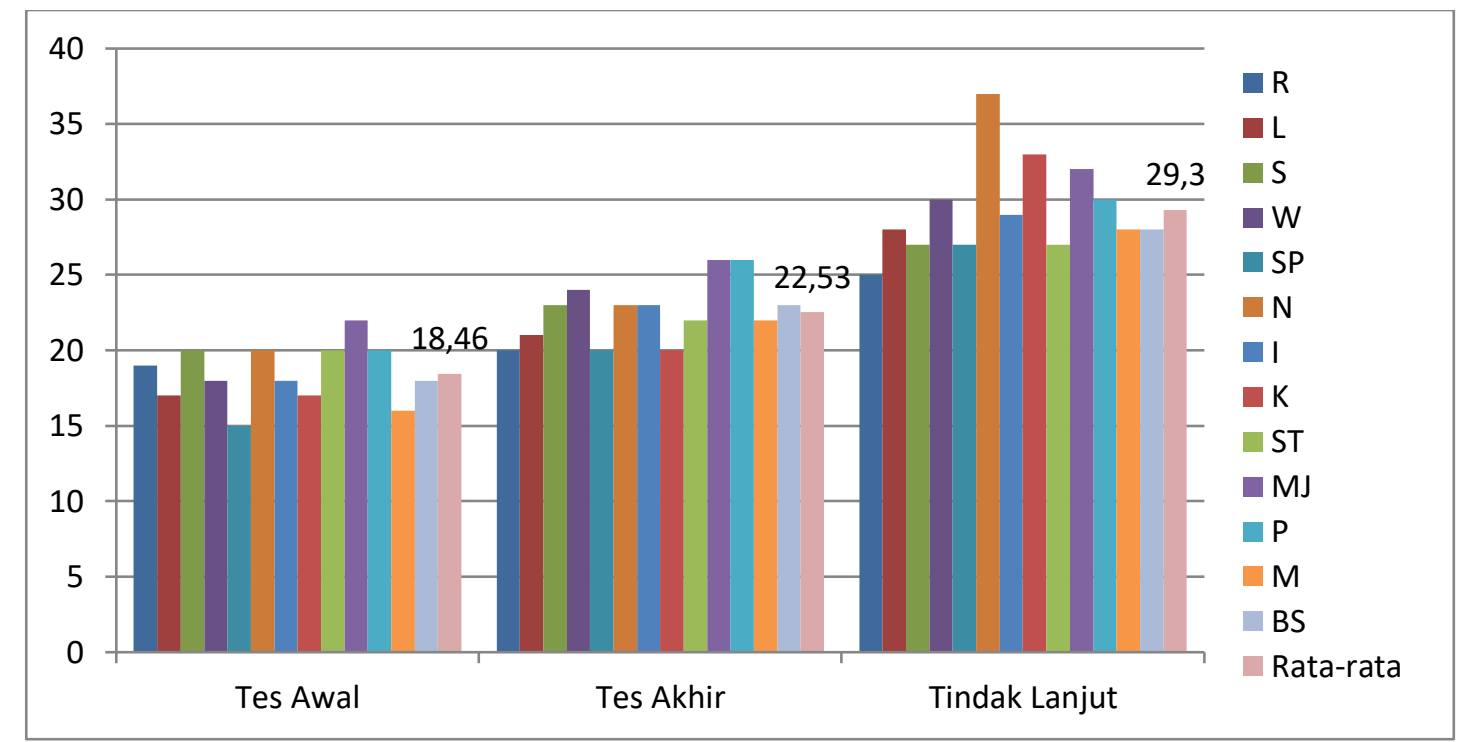

Gambar 2. Grafik Perubahan Skor Afek Positif Pada Tes Awal, Tes Akhir dan Tindak Lanjut Kelompok Eksperimen

Pada kelompok eksperimen terjadi perubahan rerata skor afek positif, yaitu dari 18,46 pada tes awal menjadi 22,53 pada tes akhir. Kedua angka tersebut terjadi peningkatan kategori yaitu dari kategori cukup tidak puas menjadi kategori cukup puas. Selanjutnya pada saat tindak lanjut rerata meningkat menjadi 29,3. Angka tersebut mengalami peningkatan dengan kategorinya dari kategori cukup puas menjadi kategori puas.

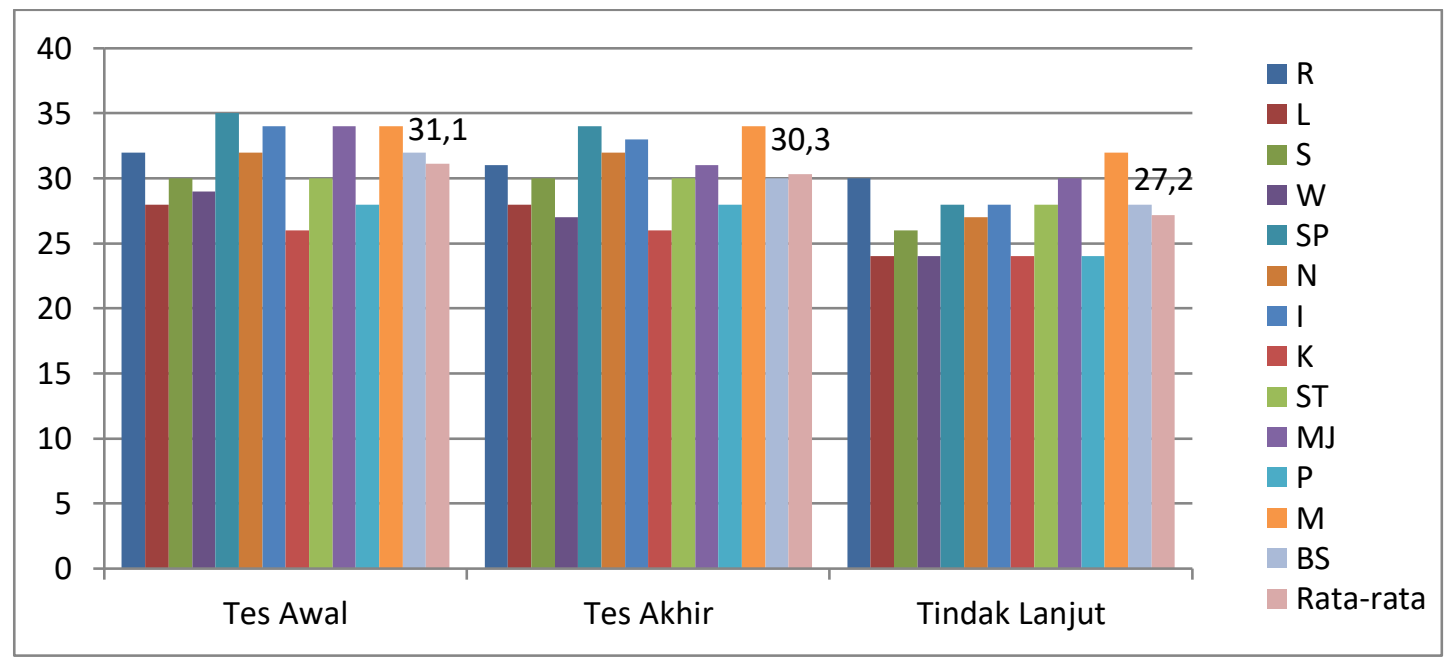

Gambar 3. Grafik Perubahan Skor Afek Negatif Pada Tes Awal, Tes Akhir, dan Tindak Lanjut Kelompok Eksperimen

Pada kelompok eksperimen terjadi perubahan rerata skor afek negatif, yaitu dari 31,1 pada tes awal menjadi 30,3 pada tes akhir. Kedua angka tersebut terjadi penurunan walau masih dalam kategori yang sama (kategori puas) dan pada saat tindak lanjut mengalami penurunan kembali menjadi 27,2. Angka tersebut mengalami penurunan dengan kategori puas menjadi kategori cukup puas. 
Berdasarkan data grafik kesejahteraan subjektif kelompok eksperimen yang terdri dari grafik kepuasan hidup, grafik afek positif, dan grafik afek negatif maka didapatkan infomasi bahwa kelompok eksperimen yang memiliki perubahan nilai kepuasan hidup tinggi adalah subjek K dengan nilai tes awal 13, tes akhir 16, dan tindak lanjut 31. Sedangkan perubahan nilai afek positif yang tinggi adalah subjek $\mathrm{N}$ dengan nilai tes awal 20, tes akhir 23 dan tindak lanjut 37. Selanjutnya perubahan nilai afek negatif yang rendah adalah subjek SP dengan nilai tes awal 35, tes akhir 34 dan tindak lanjut 38. Pada kelompok eksperimen ini juga didapatkan nilai kepuasan hidup yang rendah yaitu pada subjek BS, dengan nilai awal 12, nilai akhir 18 dan tindak lanjut 20. Selanjutnya afek positif yang mempunya nilai rendah adalah subjek S dan P. Subjek S mendapat nilai tes awal20, tes akhir 23 dan tindak lanjut 27. Subjek P mendapat nilai tes awal 20, tes akhir 26, dan tindak lanjut 30. Sedangkan subjek yang memiliki nilai afek negatif paling tinggi adalah subjek MJ dan R. Subjek MJ memiliki nilai afek negatif tes awal 34, tes akhir 31, dan tindak lanjut 30 dan subjek R memiliki nilai afek negatif tes awal 32, tes akhir 31, dan tindak lanjut 30.

Lebih lanjut grafik kelompok kontrol adalah sebagai berikut:

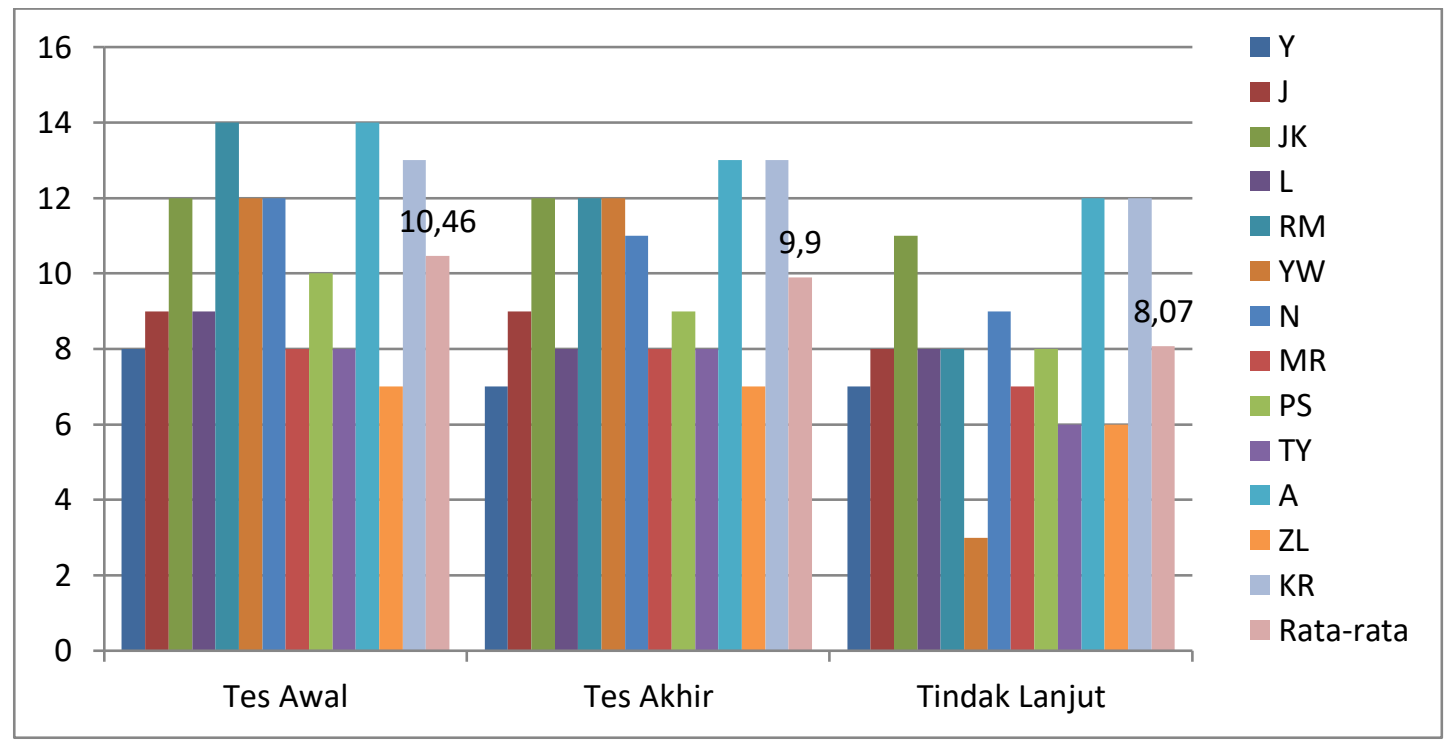

Gambar 4. Grafik Perubahan Skor SWLS (Satisfaction with Life Scale) pada Tes Awal, Tes Akhir dan Tindak Lanjut Kelompok Kontrol

Pada kelompok kontrol terjadi perubahan rerata skor SWLS (Satisfaction with Life Scale), yaitu dari 10,46 pada tes awal menjadi 9,9 pada tes akhir. Kedua angka tersebut terjadi penurunan dalam kategori tidak puas menjadi kategori sangat tidak puas dan pada saat tindak lanjut mengalami penurunan kembali walaupun masih dalam kategori yang sama yaitu menjadi 8,07. 


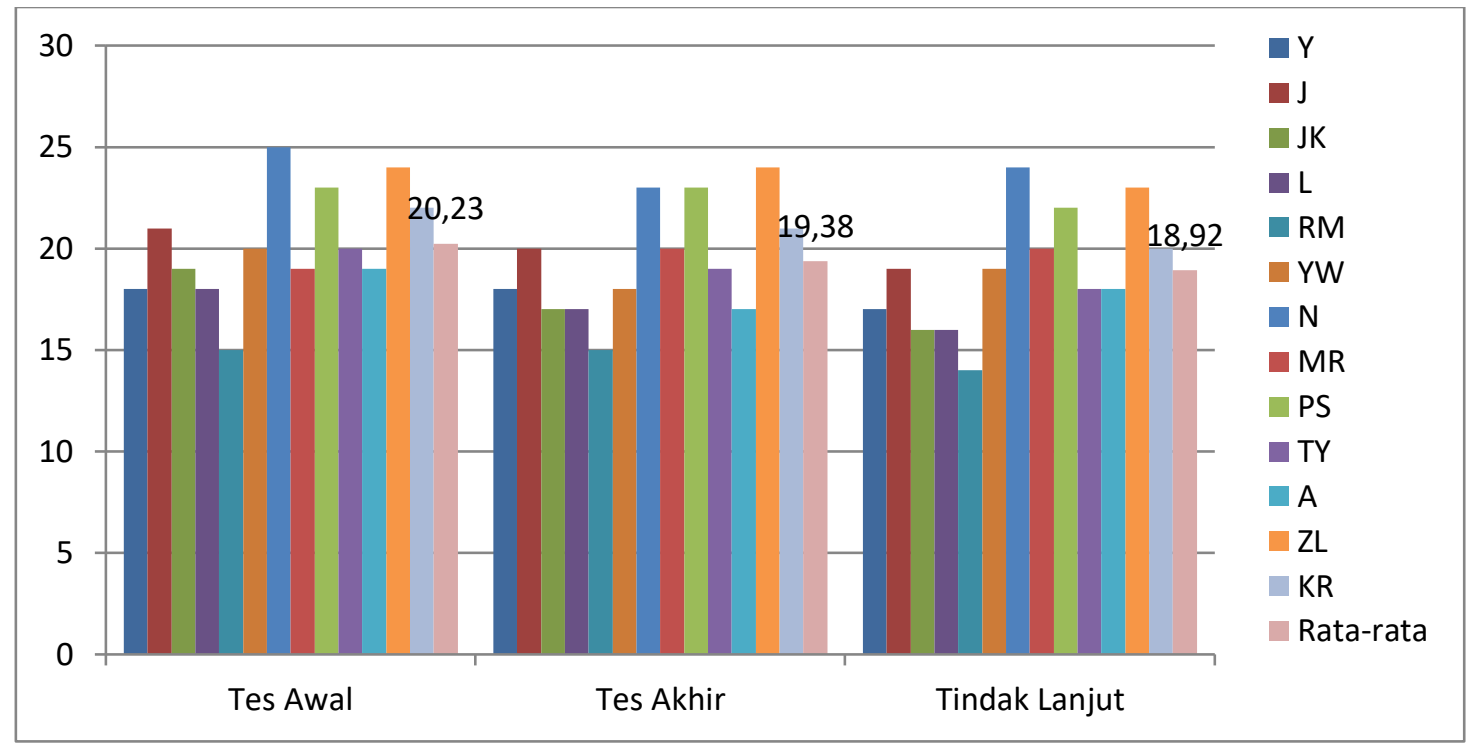

Gambar 5. Grafik Perubahan Skor Afek Positif pada Tes Awal, Tes Akhir, dan Tindak Lanjut Kelompok Kontrol

Pada kelompok kontrol terjadi perubahan rerata skor afek positif, yaitu dari 20,23 pada tes awal menjadi 19,38 pada tes akhir. Kedua angka tersebut terjadi penurunan dalam kategori normal menjadi kategori cukup tidak puas dan pada saat tindak lanjut mengalami penurunan kembali walaupun masih dalam kategori yang sama (kategori cukup tidak puas) menjadi 18,92 .

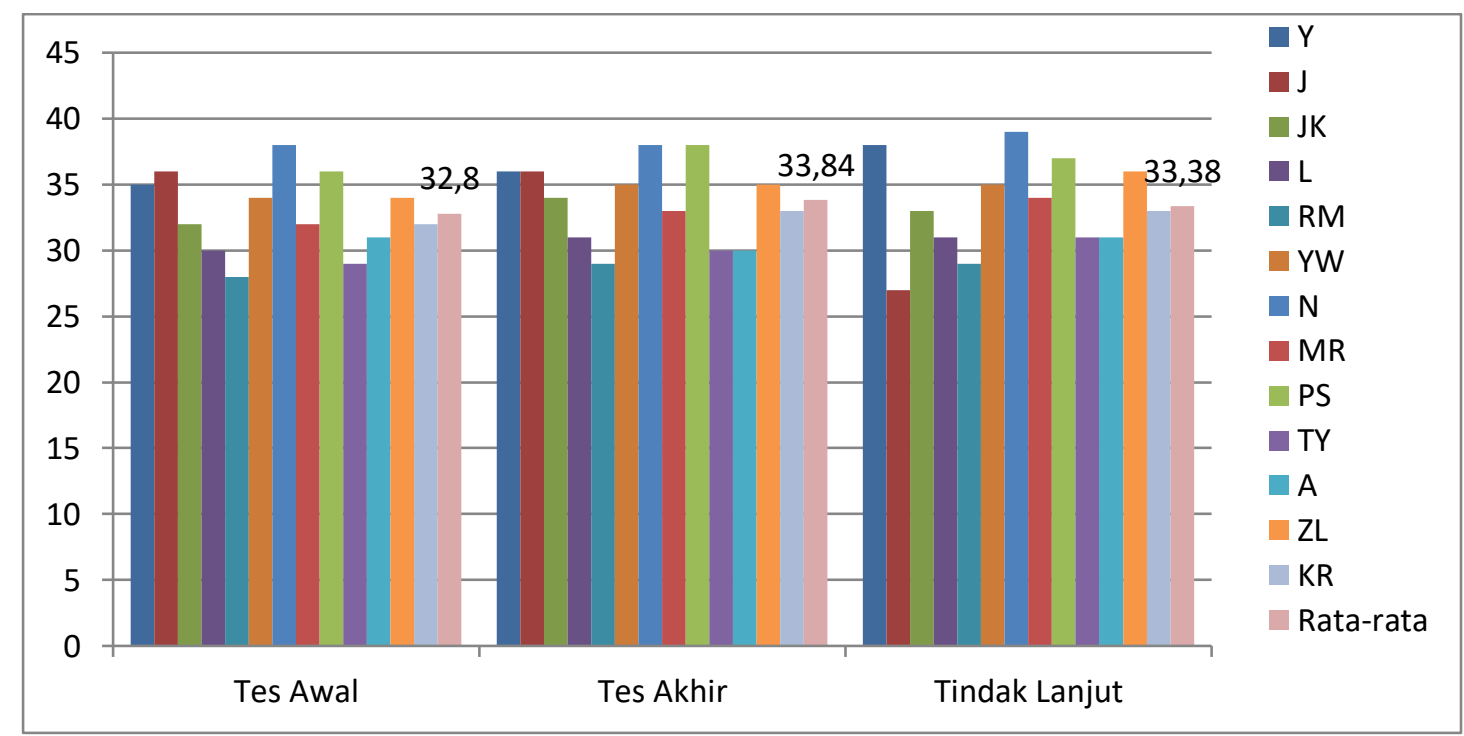

Gambar 6. Grafik Perubahan Skor Afek Negatif pada Tes Awal, Tes Akhir, dan Tindak Lanjut Kelompok Kontrol

Pada kelompok kontrol terjadi perubahan rerata skor afek negatif, yaitu dari 32,8 pada tes awal menjadi 33,84 pada tes akhir. Kedua angka tersebut terjadi peningkatan walaupun masih dalam kategori yang sama yaitu kategori sangat puas, tetapi pada saat tindak lanjut 
mengalami penurunan walaupun masih dalam kategori yang sama (kategori sangat puas) menjadi 33,38. Berdasarkan data tersebut rerata dari tes awal sampai tindak lanjut mengalami peningkatan walaupun masih dalam kategori yang samayaitu kategori sangat puas.

Berdasarkan data grafik kesejahteraan subjektif kelompok kontrol yang terdiri dari grafik kepuasan hidup, grafik afek positif, dan grafik afek negatif maka didapatkan infomasi bahwa kelompok kontrol yang memiliki perubahan nilai kepuasan hidup semakin rendah. Subjek yang memiliki kepuasan hidup yang paling rendah yaitu pada subjek YW, dengan nilai awal 12, nilai akhir 12, dan tindak lanjut 3. Sedangkan subjek yang memiliki nilai afek negatif paling tinggi adalah subjek Y. Subjek Y memiliki nilai afek negatif tes awal 35, tes akhir 36, dan tindak lanjut 38.

\section{Diskusi}

Berdasarkan hasil hipotesis dengan menggunakan analisis Independen sample t-tes ditemukan data bahwa skor tes awal menunjukkan tidak ada perbedaan yang signifikan SWLS (Satisfaction with Life Scale) antara kelompok eksperimen dan kelompok kontrol dengan Sig.(2-failed) $\mathrm{p}=0,808(\mathrm{p}<0,01)$. Hal yang berbeda ditunjukkan pada tabel tersebut pada tes akhir, bahwa ada perbedaan yang sangat signifikan, SWLS (Satisfaction with Life Scale) antara kelompok eksperimen dan kelompok kontrol pada saat tes akhir dengan nilai Sig.(2-failed) $p=0,002(p<0,01)$. Selanjutnya pada tabel saat tindak lanjut menunjukkan ada perbedaan yang sangat signifikan, SWLS (Satisfaction with Life Scale) antara kelompok eksperimen dengan kelompok kontrol dengan nilai sig. (2-failed) $p=0,000(p<0.01)$.

Selanjutnya hasil analisis aspek positif dengan menggunakan independent sampel t-tes menjunjukkan skor tes awal, tidak ada perbedaan afek positif antara kelompok eksperimen dan kelompok kontrol dengan Sig. $(2$-failed $) p=0,070(p<0,05)$. Hal yang berbeda ditunjukkan pada tabel tersebut pada tes akhir, bahwa ada perbedaan afek positif yang sangat signifikan antara kelompok eksperimen dan kelompok kontrol pada saat tes akhir dengan nilai Sig.(2-failed) $\mathrm{p}=0,003(\mathrm{p}<0,01)$. Selanjutnya pada tabel saat tindak lanjut menunjukkan ada perbedaan yang sangat signifikan, afek positif antara kelompok eksperimen dengan kelompok kontrol dengan nilai sig. $(2$-failed) $p=0,000(p<0.01)$.

Lebih lanjut hasil analisis independen sample t-tes pada afek negatif antara kelompok eksperimen dan kelompok control pada skor tes awal menunjukkan nilai Sig.(2-failed) p = $0,132(\mathrm{p}<0,05)$. Hal yang berbeda ditunjukkan pada tes akhir, bahwa ada perbedaan sangat signifikan, afek negatif antara kelompok eksperimen dan kelompok kontrol pada saat tes akhir dengan nilai Sig.(2-failed) $p=0,005(\mathrm{p}<0,01)$. Selanjutnya pada tindak lanjut 
menunjukkan ada perbedaan yang sangat signifikan, afek negatif antara kelompok eksperimen dan kelompok kontrol dengan nilai Sig.(2-failed) $p=0,000(p<0,01)$.

Berdasarkan penjelasan di atas dapat disimpulkan bahwa pelatihan regulasi emosi memengaruhi peningkatan kesejahteraan subjektif pada orang dengan hipertensi esensial. Hasil penelitian ini menguatkan pendapat Smyth \& Arigo (2009), yang menyatakan bahwa regulasi emosi sangat penting implikasinya pada kesehatan, terutama bagi individu-individu dengan sakit kronis. Selain itu sejalan dengan pendapat dari Leventhal \& Miller (dikutip dari Lewis \& Jones, 2003), yang menyatakan bahwa hubungan antara emosi dan kesehatan dapat dijelaskan melalui perspektif kausal, yaitu emosi sebagai mediator atau penyebab penyakit dan penyakit kardiovaskular merupakan hubungan langsung.

Pada pemberian pelatihan regulasi emosi ini diselipkan penjelasan materi seputar hipertensi sehingga diharapkan para peserta mampu mengetahui lebih jauh tentang hipertensi. Johnson (2006) dalam penelitiannya menemukan bahwa proses pembelajaran langsung disertai penjelasan sangat efektif membantu meningkatkan transfer ilmu, terutama ilmu yang baru, dibandingkan tanpa penjelasan. Hal tersebut didukung oleh temuan Swelleretal. (2007), bahwa belajar yang mendapatkan bimbingan secara langsung dengan menjelaskan informasi atau konsep-konsep atau prosedur-prosedur yang dibutuhkan oleh subjek mendukung terjadinya bangunan kognitif. Proses dalam pelatihan ini juga melibatkan diskusi dan umpan balik. Diskusi dan umpan balik dapat mendorong individu untuk memahami diri sendiri (Handayani, 2000).

Inti dalam pelatihan regulasi emosi adalah orang dengan hipertensi diajarkan empat keterampilan yaitu keterampilan mengenal emosi, keterampilan mengekspresikan emosi, keterampilan mengelola emosi, dan keterampilan mengubah emosi negatif menjadi emosi positif. Tahap awal pelatihan regulasi emosi ini adalah mengajarkan orang dengan hipertensi keterampilan mengenal emosi. Sebelum upaya mengekspresikan dan mengelola emosinya, orang dengan hipertensi diharapkan mengenali emosinya terlebih dahulu. Pengenalan emosi ini baik emosi positif maupun negatif. Dari hasil penelitian sebelumnya yang dilakukan oleh Ghoam (2003) menjelaskan bahwa kemampuan mengenal emosi akan dapat menghindarkan individu dari perasaan distres psikologis. Hal ini sangat berkaitan erat dengan salah satu aspek kesejahteraan subjektif yaitu rendahnya tingkat afek negatif yang dialami. Selain itu orang dengan hipertensi esensial dalam pelatihan mengungkapkan kemunculan emosi negatif seringkali mengganggu kesehatan dan pelaksanaan menejemen diri hipertensi mereka. Oleh karena itu, dengan mengenal dan menyadari adanya emosi positif dan emosi negatif akan mempengaruhi kemampuan peserta pelatihan ketika memberikan reaksi emosi secara tepat dan kemudian mengelolanya agar tidak mengganggu pelaksanaan menejemen hipertensi. 
Tahap kedua dalam proses regulasi emosi adalah keterampilan mengekspresikan emosi. Keterampilan ekspresi emosi dapat dilakukan baik dengan lisan maupun tulisan. Pada pelatihan regulasi emosi kali ini, keterampilan mengekspresikan emosi dilakukan dengan tulisan, di mana para peserta diminta menuliskan pengalaman yang berkaitan dengan perasaan dan emosi yang pernah dialaminya. Hal ini sependapat dengan hasil penelitian Smyth (1998) yang megemukakan bahwa mengekspresikan emosi melalui tulisan merupakan intervensi yang dapat memengaruhi kesehatan secara menyeluruh. Greenberg dan Stone (1992) juga menyatakan bahwa mengekspresikan emosi dapat membantu meningkatkan kesehatan, kesejahteraan psikologis dan fungsi fisik pada seseorang saat menghadapi peristiwa traumatik dalam hidupnya, membantu mengatasi distres psikologis, mengurangi emosi-emosi negatif, dan menurunkan simptom-simptom depresi.

Selanjutnya tahap ketiga dalam regulasi emosi adalah keterampilan mengelola emosi. Keterampilan mengelola emosi ini dilakukan dengan melatih teknik relaksasi, khususnya relaksasi otot. Dari hasil penelitian sebelumnya menunjukkan bahwa relaksasi, khususnya relaksasi otot bertujuan untuk mengurangi ketegangan dan kecemasan (Goldfried dan Davidson dalam Perwitasari dkk., 2003). Taylor (1995) menyebutkan bahwa teknik relaksasi otot dianjurkan dikarenakan memiliki manfaat dalam mengelola emosi yang muncul setelah peristiwa yang menekan yang menyebabkan munculnya stres, yang berkaitan erat dengan pengurangan emosi negatif yang akan berpengaruh terhadap kesejahteraan subjektif.

Tahap terakhir dalam proses regulasi emosi adalah keterampilan mengubah emosi negatif menjadi emosi positif. Pada tahap ini para peserta yaitu orang dengan hipertensi esensial diajarkan mengubah emosi negatif yang terjadi karena pola pikir negatif dan berakibat perilaku yang negatif, menjadi pola pikir yang lebih positif sehingga dapat menimbulkan emosi positif dan perilaku adaptif. Proses mengenali dan melawan emosi negatif mampu mengubah pandangan atau penilaian peserta terhadap peristiwa yang terjadi secara positif (Johnson \& Johnson, 2000). Hal ini sangat berhubungan erat dengan pencapaian kesejahteraan subjektif yang lebih baik yaitu berkurangnya emosi negatif dan meningkatnya emosi positif. Tugade dan Fredrickson (2004) menyebutkan bahwa antara emosi positif antara lain optimisme, kebahagiaan, perilaku memaafkn, harapan, cinta, maupun rasa syukur terbukti dapat mengatasi dan mengurangi kesenderungan stres dan depresi. Individu yang memilki emosi positif lebih dapat bersikap adaptif terhadap berbagai stresor kehidupan.

Oleh karena itu kesejahteraan subjektif sebagai pendekatan psikologis juga merupakan suatu tujuan penting dalam menejemen atau pengelolaan hipertensi esensial, tidak hanya pengelolaan atau menejemen secara medis saja. Hal ini setidaknya dapat membantu memprediksi ada atau tidaknya maalah-masalah psikologis maupun komplikasi yang terjadi 
(McCraty, Aktinson, dan Lipsenthal, 2000). Pentingnya pendekatan psikologis khususnya permasalahan kesejahteraan subjektif pada orang dengan hipertensi esensial karena hal ini sangat berkaitan erat dengan pelaksanaan manajemen hipertensi yang tentu saja akan berpengaruh terhadap kesehatan fisik.

Sependapat dengan Peyrotdkk (2005) yang menyatakan bahwa adanya dampak pada ketaatan dalam melaksanakan aturan-aturan pengelolaan penyakit hipertensi yang disebabkan oleh masalah-masalah psikologis dan rendahnya kesejahteraan psikologis. Meningkatnya rasa sedih, patah semangat terhadap masa depan, merasa sangat letih, dan mengalami penurunan kepercayaan diri maupun disiplin diri dapat terjadi seiring dengan buruknya kesehatan fisik (Hayes dan Ross dalam Temane dan Wissing, 2006). Dapat dikatakan bahwa kesejahteraan subjektif adalah upaya terhadap penyakit hipertensi untuk dapat menjaga kondisi glukosa darah pada tingkat rata-rata atau normal sehingga mengalami peningkatan kesehatan.

Sejalan dengan itu, proses-proses yang dialami selama pelatihan regulasi emosi ini sangat berkaitan erat dengan peningkatan kesejahteraan subjektif pada orang dengan hipertensi esensial. Keterampilan yang diajarkan selama pelatihan merupakan upaya dalam meningkatkan kepuasan hidup, mengurangi emosi negatif dan meningkatkan emosi positif berupa motivasi baru dan optimis yang dapat membantu perkembangan kesejahteraan subjetif dalam jangka panjang (Schneider, 2001). Hal tersebut tentu saja sangat berpengaruh terhadap kesehatan orang dengan hipertensi esensial.

\section{Simpulan}

Setelah dilakukan penelitian untuk membuktikan hal ini, maka dapat ditarik kesimpulan untuk menjawab tujuan utama maupun kesimpulan tambahan berdasarkan beberapa temuan selama proses eksperimen. Penelitian ini membuktikan bahwa ada perbedaan kesejahteraan subjektif orang dengan hipertensi yang mengikuti pelatihan regulasi emosi dengan orang dengan hipertensi yang tidak mengikuti pelatihan regulasi emosi. Orang dengan hipertensi memiliki kesejahteraan subjektif yang tinggi setelah mendapatkan pelatihan regulasi emosi dibandingkan dengan orang dengan hipertensi yang tidak mendapatkan pelatihan regulasi emosi. Pernyataan tersebut sesuai dengan hasil yang didapatkan berupa orang dengan hipertensi yang mengikuti pelatihan regulasi emosi memiliki kepuasan hidup yang tinggi dibandingkan orang dengan hipertensi yang tidak mengikuti pelatihan regulasi emosi. Didapatkan hasil juga bahwa orang dengan hipertensi yang mengikuti pelatihan regulasi emosi memiliki afek positif yang tinggi dibandingkan orang dengan hipertensi yang tidak mengikuti pelatihan regulasi emosi. Selanjutnya orang dengan hipertensi yang mengikuti pelatihan regulasi emosi memiliki afek negatif yang 
rendah dibandingkan orang dengan hipertensi yang tidak mengikuti pelatihan regulasi emosi.

Analisis kualitatif menemukan bahwa individu-individu mengalami proses pelatihan regulasi emosi dan peningkatan skor kesejahteraan subjektif yang berbeda-beda. Pada aspek kepuasan hidup, seluruh subjek mengungkapkan bahwa merasa kehidupannya menjadi lebih baik. Sedangkan pada aspek afek positif yang meningkat adalah merasa lebih sabar, optimis, tenang, bersyukur, ikhlas, percaya diri, gigih, tidak mudah marah dan tersinggung, kuat, bertekad, gembira, dan menjadi lebih fokus dalam melakukan pekerjaan. Afek positif yang paling dominan dirasakan oleh seluruh subjek penelitian adalah merasa lebih sabar, optimis dan tenang. Sedangkan pada aspek afek negatif yang berkurang adalah perasaan takut, rasa bersalah, kecewa, bermusuhan, malu, gelisah, sedih, jengkel, cemas, tertekan, dan tersinggung. Afek negatif yang paling dominan dirasakan oleh subjek adalah berkurangnya perasaan takut. Faktor-faktor yang menyebabkan munculnya perbedaan hasil pelatihan regulasi emosi ini adalah kondisi berbeda yang dilami peserta pelatihan, seperti kondisi kesehatan dan permasalah yang dihadapi, serta kemampuan peserta dalam menyerap materi-materi pelatihan dan proses belajar yang berbeda pada setiap peserta.

\section{DAFTAR PUSTAKA}

DeRidder, D., Geenen,R., Kuijer, R.,\& vanMiddendorp, H. (2008). Psychological adjustment to chronic disease. Review, vol 372, www.thelancet.com.

Diener, E., Scollon, N. C. \& Lucas, R. E. 2003. The Evolving Concept of Subjective Well Being: The Multifaced nature of Happines. Advances in Cell Aging and Gerontology, 15, 187-219

Greenberg, L. S. 2002. Emotion Focused Therapy: CoachingClientstoWorkThroughTheir Feelings. Washington, DC: American Psychological Association

Greenberg, M. A, \&Stone, A. A., 1992. Emotional Disclosure Abot Traumasandits RelationtoHealth: Effectof Previous Disclosureand Trauma Severity. Journal of Personality and Social Psychology, 63 (1), 75-84.

Ghoam, C. 2003. Mood Regulation and Emotion Intelligence: Individual Differences. Journal of Personality and SocialPsychology

Perwitasari, J. E. 1992. "Konseling dan Psikoterapi". Hand Out Assesment dan Inteervensi. Yogyakarta: Tidak diterbitkan. Universitas Gajah Mada.

Prasetyorini, H. T., Prawesti, D., 2012. Stres pada Penyakit terhadap Kejadian Komplikasi Hipertensi pada Pasien HipertensiAvailablefrom :http://download.portalgaruda.org/article.php?article=4235\&val=360[Accessed 24 Mei 2015

Salas, E. \& Cann0n- Bowers, J. A. 2001. The Science of Training: Adecade of Progress. Annual Review of Psychology. 52, 471-499. 
Smyth, J. M. 1998. Written Emotional Expression: EffectSizes, OutcomeTypes, andModeratingVariables. PsycholoicalBulletin. 66, 1, 174-184.

Taylor, S. E. 2006. Health Psychology. New York. McGraw-Hill Companies, Inc.

Temane, Q. M. \& Wissing, M. P. 2006. The Role of Subjective Perception of Health in Dynamics of Context and Psychological Well Being . South African Journal of Psychology, 36, 3, 564-581.

Tugade, M. M. \& Fredrickson, B. L. 2004. Resilient Individual Use Positive Emotions to Bounce Back from Negative Emotional Experiences. Journalof Personality and Social Psychology, 86, 2. 320-333. 